\title{
EFEK PEMBERIAN MAKANAN TAMBAHAN BISKUIT TERHADAP KONSENTRASI FERITIN IBU HAMIL DI KOTA PAREPARE
}

\section{BISCUITS SUPPLEMENTARY FEEDING EFFECT ON THE CONCENTRATION OF FERITIN IN PREGNANT WOMEN AT PAREPARE CITY}

\author{
Hasra Ryska ${ }^{1}$, Aminuddin Syam ${ }^{2}$, Ida Leida ${ }^{3}$ \\ ${ }^{1}$ Bagian gizi, Fakultas Kesehatan Masyarakat, Universitas Hasanuddin \\ ${ }^{2}$ Bagian Gizi, Fakultas Kesehatan Masyarakat, Univesitas Hasanuddin \\ ${ }^{3}$ Bagian Epidemiologi, Fakultas Kesehatan Masyarakat, Universitas Hasanuddin
}

Alamat Korespondensi: Fakultas Kesehatan Masyarakat, Universitas Hasanuddin Makassar

Email: hasraryska150692@gmail.com

\begin{abstract}
ABSTRAK
Makanan tambahan ibu hamil berupa biskuit lapis yang dibuat dengan formulasi khusus dan difortifikasi dengan vitamin dan mineral yang diketahui dapat mencukupi kebutuhan gizi ibu hamil. Penelitian ini bertujuan untuk melihat efek Pemberian Makanan Tambahan biskuit terhadap konsentrasi feritin ibu hamil KEK di Kota Parepare tahun 2018. Penelitian ini adalah Penelitian Kuantitatif dengan pendekatan Longitudinal (Time-Period Approach), jumlah sampel pada penelitian ini 42 ibu hamil yang dipilih secara purposive sampling. Data meliputi Konsumsi Biskuit yang diperoleh dari lembar observasi sedangkan hasil feritin didapatkan dari pengambilan serum dan hasil pemeriksaan di Laboratorium. Hasil penelitian dengan menggunakan uji regresi logistik menunjukkan bahwa ada pengaruh pemberian makanan tambahan biskuit terhadap konsentrasi ferritin ibu hamil $p=0,024$. Ada pengaruh usia terhadap konsentrasi ferritin $\mathrm{p}=0,021$. Analisis multivariat menunjukkan konsumsi biskuit berpengaruh terhadap konsentrasi ferritin $(\mathrm{p}=0,024 ; \operatorname{Exp}(\mathrm{B})=0,636)$ begitupun usia berhubungan bermaknan dengan kadar ferritin ibu hamil $(\mathrm{P}=0,033$; $\operatorname{Exp}(B)=8,352)$ Disimpulkan bahwa ada pengaruh pemberian makanan tambahan biskuit dan usia terhadap konsentrasi feritinin ibu hamil. Pemberian PMT dapat diberikan pada wanita sejak diinkasi hamil positif dan memiliki status gizi yang buruk. Pemberian pendidikan tentang asupan gizi yang baik dapat diberikan pada wanita hamil untuk meningkatkan pengetahuan dan kesadaran pentingnya asupan gizi yang baik selama kehamilan.
\end{abstract}

Kata Kunci : Ibu Hamil, Makanan Tambahan Biskuit, Feritin

\begin{abstract}
ABSTRAK
Supplementary food of pregnant women in the form of layer biscuits made with special formulations and fortified with vitamins and minerals that are known to meet the nutritional needs of pregnant women. This study aims to see the effect of Supplementary Food Feeding biscuits on the concentration of feritin KEK pregnant women in Parepare City 2018. This research is Quantitative Research with Longitudinal approach (Time-Period Approach), the number of samples in this study 42 pregnant women selected by purposive sampling. The data includes the consumption of biscuits obtained from the observation sheet while the ferritin results obtained from the serum taking and the results of the laboratory examination. The result of the research by using logistic regression test showed that there is influence of supplementary food feeding biscuit to ferritin concentration of pregnant women $p=0,024$. There was an effect of age on ferritin concentration $p=0,021$. Multivariate analysis showed that biscuit consumption had an effect on ferritin concentration $(p=0,024 ; \operatorname{Exp}(B)=0,636)$ as well as age correlated with ferritin pregnant women $(P=0,033 ; \operatorname{Exp}(B)=8,352)$ and age to the concentration of ferinin pregnant women. Giving PMT can be given to women since pregnancy positive pregnancy and have poor nutritional status. Providing education on good nutrition can be given to pregnant women to increase knowledge and awareness of the importance of good nutrition during pregnancy.
\end{abstract}




\section{PENDAHULUAN}

Angka kematian ibu yang tinggi masih terus berlanjut dan tetap masih merupakan masalah kesehatan di Negara sedang berkembang. Menurut World Health Organization (WHO) kematian tertinggi di Asia Selatan yaitu 12,8\% karena pendarahan post partum yang disebabkan anemia. Keterbatasan akses bahan makanan bergizi dengan masa laktasi yang lama menyebabkan terjadinya deplesi gizi maternal seperti zat besi dan vitamin A, serta pembatasan makan selama kehamilan menyebabkan anemia dan pada akhirnya anak lahir dengan Berat Bayi Lahir Rendah (BBLR)(Melku, Addis, Alem, \& Enawgaw, 2014).

Menurut World Health Statistic pada tahun 2015, sekitar 830 wanita meninggal setiap hari karena komplikasi selama kehamilan atau persalinan. Penurunan rasio kematian ibu secara global dari 216 per 100.000 kelahiran hidup di 2015 menjadi 70 per 100.000 kelahiran hidup di tahun 2030 akan membutuhkan tingkat penurunan tahunan secara global paling sedikit 7,5\%(WHO, 2015).

Kadar feritin merupakan salah satu indikator yang dipakai untuk melihat status besi seseorang (Gibson, 2005). Akan tetapi kadar feritin yang tinggi tidak selalu menunjukkan cadangan besi yang berlebih. Pada kondisi infeksi akut kadar eritropoetin meningkat dan dapat menyebabkan meningkatnya kadar feritin, namun setelah infeksi menghilang kadar eritropoetin akan normal kembali (Kraemer \& Zimmermann, 2007).

Pada penelitian yang bertujuan untuk melihat korelasi status gizi, asupan zat besi dengan kadar ferritin didapatkan hasil yang menunjukkan bahwa terdapat hubungan antara status gizi, asupan zat besi terhadap kadar ferritin (Sunarti, 2014). Penelitian yang lain dilakukan di Depok untuk melihat kadar ferritin serum pada ibu hamil trimester I menunjukkan hasil bahwa kadar ferritin serum rendah ditemukan pada 21 (30,9\%) subyek penelitian dan $47(69,1 \%)$ yang ferritinnya normal (Partinah, 2017).

Berdasarkan uraian diatas, peneliti tertarik untuk meneliti tentang efek pemberian makanan tambahan biskuit terhadap konsentrasi ferritin ibu hamil di kota Parepare.

\section{BAHAN DAN METODE}

\section{Lokasi dan rancangan penelitian}

Penelitian ini dilakukan di kota Parepare dengan fokus 6 wilayah kerja puskesmas, yaitu puskesmas Madising, Lumpue, Lakessi, Lompoe, Lapadde, dan Cempae. Jenis penelitian adalah kuantitaif dengan pendekatan longitudinal (TimePeriod Aproach).

\section{Populasi dan sampel}

Populasi adalah seluruh ibu hamil KEK yang berada diwilayah kerja puskesmas Madising, Lumpue, Lakessi, Lompoe, Lapadde, dan Cempae. Sampel 
sebanyak 42 orang yang dipilih secara purposive sampling yang telah memenuhi kriteria inklusi yaitu ibu hamil KEK dan mendapatkan makanan tambahan biskuit, telah diambil serumnya pada bulan ke 3 setelah mengkonsumsi biskuit, serta bersedia untuk mengikuti penelitian ini dengan menandatangai informed consent yang telah dikeluarkan oleh Komite Etik Fakultas Kesehatan Masyarakt Universitas Hasanuddin.

\section{Metode pengumpulan data}

Pengumpulan data meliputi karakterstik (pendidikan, pekerjaan, agama, suku) faktor maternal (Usia, paritas) dan asupan zat gizi makro diukur dengan wawancara menggunakan kuesioner. Konsumsi Biskuit diperoleh dari lembar observasi sedangkan hasil feritin diukur dengan melakukan pemeriksaan di laboratorium dengan menggunakan metode ELISA yang pengambilan serumnya dilakukan oleh petugas lapangan terlatih dari pengambilan serum dan hasil pemeriksaan di Laboratorium.

\section{Analisis Data}

Data yang diperoleh diolah dengan menggunakan program SPSS for windows 11.5 dengan analisis univariat, bivariat dan multivariat. Hasil analisis akan dinarasikan dan ditabelkan. Untuk uji statistik, tingkat kemaknaan yang digunakan $p \leq 0,05$.

\section{HASIL}

\section{Karakteristik sampel}

Tabel 1 memperlihatkan karakteristik ibu hamil yang menjadi sampel penelitian ini. Sebagian besar ibu hamil dengan latar belakang penddikan SMA dan Perguruan tinggi 14 orang $(33,3 \%)$ dengan pekerjaan sebagai ibu rumah tangga 32 (76,2\%). usia lebih banyak yang beresiko rendah 36 orang $(85,7 \%)$ dengan kadar ferritin normal.

\section{Analisis Bivariat}

Tabel 2 menunjukkan ada pengaruh pemberian makanan tambahan biskuit terhadap konsentrasi ferritin ibu hamil $\mathrm{p}=0,024 ; \operatorname{Exp}(\mathrm{B})$ 0,636 kemudian usia juga berpengaruh terhadap konsentrasi ferritin ibu hamil $\mathrm{p}=0,021$, paritas tidak berpengaruh terhadap konsentrasi ferritin $\mathrm{p}=1.00$

\section{Analisis Multivariat}

Tabel analisis regresi logistik menunjukkan ada pengaruh konsumsi biskuit terhadap ferritin $\mathrm{p}=0,024$ dan usia juga berpengaruh terhadap konsentrasi ferritin 0,021 (tabel 3). 
Tabel 1. Distribusi subjek penelitian menurut karakteristik sosial demografi

\begin{tabular}{ccc}
\hline \multicolumn{1}{c}{ Karakteristik } & n & \% \\
\hline Tingkat Pendidikan & & 2,4 \\
Tidak pernah sekolah & 1 & 9,5 \\
Tamat SD & 4 & 21,4 \\
SMP & 9 & 33,3 \\
SMA & 14 & 33,3 \\
Perguruan Tinggi & 14 & 76,2 \\
Pekerjaan & & 2,4 \\
IRT & 32 & 9,5 \\
Pegawai Swasta & 1 & 11,9 \\
PNS & 4 & \\
Lainnya & 5 & 83,3 \\
Suku & & 7,1 \\
Bugis & 35 & 2,4 \\
Toraja & 3 & 7,1 \\
Mandar & 1 & 88,1 \\
Lainnya & 3 & 2,4 \\
Agama & & 7,1
\end{tabular}

Tabel 2. Analisis pengaruh konsumsi biskuit terhadap feritin

\begin{tabular}{cc|cc}
\hline Hubungan & $\operatorname{Exp}(\mathrm{B})$ & P-Value & Keputusan \\
\hline $\begin{array}{c}\text { Konsumsi Biskuit terhadap } \\
\text { Konsentrasi Feritin }\end{array}$ & 0.636 & 0.024 & $\mathrm{H}_{1}$ Diterima \\
\hline Uji Regresi Logistik & &
\end{tabular}

Tabel 3. Analisis hubungan variabel bebas dengan variabel terikat

\begin{tabular}{cccc}
\hline Step & Variabel & Nilai $\mathrm{p}$ & $\operatorname{Exp}(\mathrm{B})$ \\
\hline 1 & Konsumsi Biskuit & 0,024 & 0,636 \\
& Usia & 0.033 & 8.352 \\
\hline
\end{tabular}

\section{PEMBAHASAN}

Dalam penelitian ini terlihat bahwa ada pengaruh yang signifikan antara pemberian makanan tamabahan biskuit terhadap konsentrasi feritin dan pengaruh usia terhadap konsentrasi feritin.

Peningkatan kadar ferritin serum menunjukkan peningkatan cadangan besi tubuh. Cadangan besi dalam tubuh berkorelasi dengan kadar ferritin serum. Ferritin intraselular diproduksi oleh smooth endoplasmic reticulum (SER) dan ferritin plasma disintesis oleh rough endoplasmic reticulum (RER) serta diglikolisasi oleh apparatus golgi. Pada keadaan normal, jumlah ferritin plasma yang disintesis dan disekresi proporsional dengan jumlah ferritin selular yang diproduksi dalam the internal iron storage pathway, sehingga konsentrasi ferritin plasma berhubungan degan penimbunan besi dalam tubuh (Hirata, et all). 
Cadangan inilah yang akan disinteis ketika tubuh ibu hamil kekurangan $\mathrm{Hb}$ untuk meningkatkan $\mathrm{Hb}$ sehingga proses kehamilan tetap berjalan normal.

Temuan lain juga sejalan dengan temuan ini yaitu adanya korelasi antara asupan Zat Besi dengan feritin. Kontribusi asupan $\mathrm{Fe}$ dalam peningkatan kadar feritin sebesar 1,747 $\mu \mathrm{g} / \mathrm{L}$. Feritin merupakan prediktor terpercaya sebagai penentu status $\mathrm{Fe}$ pada tubuh manusia termasuk ibu hamil. Rendahnya feritin merupakan indikasi kurangan cadangan $\mathrm{Fe}$ dalam tubuh (Sunarti, 2014).

Penelitian ini juga menemukan bahwa ada hubungan antara usia ibu dengan kadar ferritin. Salah satu faktor yang behubungan dengan kejadian anemia pada ibu hamil adalah usia. Semakin muda umur ibu hamil, semakin berisiko untuk terjadinya anemia. Hal ini didukung oleh penelitian Adebisi dan Strayhorn (2015) di Amerika Serikat bahwa ibu remaja memiliki prevalensi anemia kehamilan lebih tinggi dibanding ibu berusia 20 sampai 35 tahun. Hal ini dapat dikarenakan pada remaja, Fe dibutuhkan lebih banyak karena pada masa tersebut, remaja membutuhkannya untuk pertumbuhan, jika ia hamil maka kebutuhan akan Fe lebih besar. Selain itu, faktor usia yang lebih muda berkaitan dengan pekerjaan, status sosial ekonomi dan pendidikan yang kurang. Hal ini tidak sejalan dengan penelitian ini yang megatakan bahwa usia ibu yang beresiko tinggi 20-35 tahun lebih beresiko kadar ferritin tidak normal. Meskipun sebenarnya jika ibu anemia belum tentu cadangan zat besi dalam tubuh juga tidak normal.

Penelitian ini juga menemukan hasil bahwa tidak ada hubungan antara konsumsi protein dengan feritinin, hal ini tidak sejalan dengan penelitian. Andriana dkk (2006) yang menemukan hasil bahwa ada hubungan antara konsumsi protein dengan level hemoglobin. Hal ini menunjukkan bahwa responden dengan asupan protein rendah lebih berisiko defisiensi. Jika dibandingkan dengan responden yang asupan proteinnya cukup. Tidak adanya hubungan antara konsumsi protein dengan ferritin pada penelitian ini adalah karena makanan yang dikonsumsi/asupan zat gizi yang dikonsumsi reponden tidak di control oleh peneliti. Padahal jika melihat kandungan Protein, protein justru memegang peranan esensial dalam mengangkut zat-zat gizi dari saluran cerna melalui dinding saluran cerna ke dalam darah, dari darah kjnkjiouiie jaringan-jaringan dan melalui membran sel kedalam sel-sel. Sebagai alat angkut, protein ini dapat bertindak secara khusus, misalnya protein pengikat retinol yang hanya mengangkut vitamin $\mathrm{A}$. atau dapat mengangkut beberapa jenis zat gizi seperti besi sebagai transferrin (Almatsier 2003). Protein sebagai alat angkut dan penyimpanan terhadap haemoglobin yaitu 
mengangkut oksigen dalam otot, ion besi diangkut dalam plasma darah oleh transferrin dan disimpan dalam hati sebagai kompleks dengan ferritin.

Terutama protein hewani, walaupun tidak semua, juga dapat mendorong penyerapan besi non heme. Protein seluler yang berasal dari daging sapi, kambing, domba, hati, dan ayam menunjang penyerapan besi non heme. Namun protein yang berasal dari susu sapi, keju dan telur tidak dapat meningkatkan penyerapan besi dan lebih dikenal sebagai MFP (meet, fish, poultry).

Hasil penelitian ini juga mengemukakan bahwa, tidak ada hubungan antara konsumsi lemak dengan kadar ferritin, penelitian ini sejalan Sejalan dengan temuan Gartner et al (2013) yang memberikan hasil bahwa wanita usia subur yang menderita kegemukan akan mengalami defisiensi besi. Bertentangan dengan temuan Sudikno \& Sandjaya (2016) yang menemukan hasil bahwa tidak ada hubungan bermakna antara IMT dengan kejadian anemia pada WUS. Anemia justru cenderung terjadi pada WUS dengan IMT kurang dari $18,5 \mathrm{~kg} / \mathrm{m}^{2}$, dibandingkan kelompok WUS dengan IMT 18,5 - 24,9 kg/m $\mathrm{m}^{2}$ (normal). Pengaruh kegemukan atau kelebihan asupan lemak dengan kejadian anemia sampai saat ini masih belum jelas. Kegemukan atau asupan gizi berlebih bisa jadi faktor prediktor dan bisa jadi faktor protektif terhadap konsentrasi hemoglobin.

Defisiensi besi pada wanita kelebihan lemak mungkin disebabkan karena rendahnya asupan besi. Sementara penyebab normalnya zat besi pada orang yang asupan lemak berlebih yaitu karena asupan makanan sumber zat besinya tinggi. Asupan lemak berlebih menyebabkan terjainya inflamasi sitemik yang berdampak negatif pada regulasi besi. Jaringan lemak akan melepaskan sitokin dan menyebabakan inflamasi sistemik yang berhubungan dengan patogenesis penyakit metabolik dan penyakit degeneratif. Lemak akan tertimbun pada hati, sehingga memicu pembentukan peroksida lipid kemudian mempengaruhi metabolisme besi maka terjadilan pelepasan radikal bebas. Hal ini yang menyebabkan terganggunya sintesis $\mathrm{Hb}$.

\section{KESIMPULAN DAN SARAN}

Kami menyimpulkan bahwa ada pengaruh pemberian makanan tambahan biskuit terhadap konsentrasi feritin dan ada pengaruh usia terhadap konsentrasi ferritin ibu hamil. Upaya pemberian makanan tambahan biskuit dapat diberikan pada wanita sejak diindikasi hamil positif dan memiliki status gizi yang buruk, melalui edukasi tentang asupan gizi yang baik dapat diberikan pada wanita hamil untuk meningkatkan pengetahuan dan kesadaran pentingkan asupan gizi yang baik selama kehamilan. 


\section{DAFTAR PUSTAKA}

Adebisi LS. (2015). Buku Saku : Anemia Defisiensi Besi Masa Prahamil \& Hamil. Jakarta : EGC

Almatsier, S. Prinsip Dasar Ilmu Gizi, Jakarta : PT Gramedia Pustaka Utama, 2005.

Andriana, D. Sumarmi, S. "Hubungan Konsumsi Protein Hewani dan Zat Besi dengan Kadar Hemoglobin pada Balita Usia 13 - 36 Bulan", Indonesian Journal of Public Health, Vol/No: 3 (1). Pp. 19-23, 2006

Gartner et al., 2013. A Double Burden of Overall or Central Adiposity and Anemia of Iron Deficiency is prevalent but with Little Socioeconomic Patterning Among Moroccon and Tunisian Urban Women. The Journal of Nutrition, pp.jn-113

Gibson R.S. (2005). Principle of Nutritional Assessment. Second Edition, Oxford University Press, New York.

Hirata, A. M. et al. (2017) 'Nutrire Effect of the Brazilian iron fortification of wheat and corn flour on the nutritional iron status in adolescents , 6 years after its implementation', Nutrire. Nutrire, 42(11), pp. 1-6

Kraemer, K., \& Zimmermann, M. B. (2007). Nutritional Anemia. SIGHT AND

LIFE

Press.Retrievedfromhttp://www.sigh tandlife.org/fileadmin/data/Books/Nu tritional_anemia_book.pdf

Melku, M., Addis, Z., Alem, M., \& Enawgaw, B. (2014). Prevalence and Predictors of Maternal Anemia during $\backslash r$ Pregnancy in Gondar, Northwest Ethiopia: An Institutional $\backslash$ rBased Cross-Sectional Study. Hindawi Publishing Corporation, 2014, 1-9.

Partinah, R. (2017). Gambaran Kadar Ferritin Serum Wanita Hamil Trimester I Di Rumah Sakit Umum Hasanah Graha Afiah Depok Oleh:
Uin Syarif Hidayatullah, (April 2016).

Sudikno, S. And Sandjaja,S., 2016. Prevalensi dan Faktor Risiko Anemia pada wanita usia subur di rumah tangga miskin di Kabupaten Tasikmalaya dan Ciamis, Provinsi Jawa Barat. Jurnal Kesehatan Reproduksi, 7 (2), pp. 71-82.

Sunarti. (2014). Korelasi Status Gizi, Asupan Zat Besi dengan Kadar Feritin pada Anak Usia 2-5 Tahun di Kelurahan Semanggi Surakarta. Kesmas, 8(1), 11-18.

World Health Organization. (2015). Health Statistics and Information Sistem. 